Review

\title{
Interactions between polyphenols and polysaccharides: Mechanisms and consequences in food processing and digestion
}

\author{
Catherine M.G.C. Renard*, Aude A. Watrelot ${ }^{1}$, Carine Le Bourvellec \\ UMR408 SQPOV Sécurité et Qualité des Produits d'Origine Végétale, Domaine Saint Paul, INRA, Avignon University, F-84000 Avignon, France
}

A B S T R A C T

Background: Interactions between intracellular polyphenols and plant cell-walls have received little attention, due to analytical limitations. It was difficult until recently to analyse the most implicated polyphenols, which are proanthocyanidins (aka condensed tannins), and because these weak interactions were too low for quantification. They are becoming recognized as a factor to understand extractability, functional and health effects of polyphenols.

Scope and approach: New approaches that have been used since the turn of the century are binding isotherms and isothermal titration calorimetry. They allow to investigate specifically these interactions,

Keywords:

Proanthocyanidin

Plant cell-walls

Pectin

Adsorption

Extractability

Bioavailablity quantify the affinities between cell-walls and polyphenols as well as the impact of fruit maturation or processing, and the consequences on the finished beverages and food. This review will highlight results on this topic since 2001.

Key findings and conclusions: The most common polyphenols are phenolic acids and oligo or polymeric flavanols (proanthocyanidins), located inside the vacuole in intact plant cells. The proanthocyanidins bind spontaneously to the plant cell-wall polysaccharides through plant tissue disruption, for example during grinding, mastication or thermal treatments, etc. The highest affinity is observed with pectins, which may help explain some of the effects of maturation on polyphenol extractability, e.g. in wine making. Presence of proanthocyanidins together with the cell-walls in the lower gut further impacts on the production of colonic metabolites. This has profound consequences on the extractability and bioavailability of the polyphenols, on the functional characteristics of extracted polysaccharides, and on the fermentation kinetics of dietary fibers and polyphenols.

\section{Introduction}

In intact plant tissues, cell-walls, polyphenols and polyphenoloxidase (PPO) are present in distinct compartments. When cells are ruptured, e.g. by grinding and pressing, these three elements come in contact. Polyphenols react with cell-wall polysaccharides and can be oxidised by PPO. Winemakers, those who treat external timber with creosote, or laboratory workers using any form of chromatography all know this. The literature however when we started working on this topic in 1999 was sparse and disperse, in contrast to the abundance of data for protein/

* Corresponding author. UMR408 SQPOV, INRA, Site Agroparc, 228 route de l'Aérodrome, CS-40509, 84914 Avignon Cedex 9, France.

E-mail addresses: catherine.renard@inra.fr (C.M.G.C. Renard), watrelotaude@ yahoo.fr (A.A. Watrelot), carine.le-bourvellec@inra.fr (C. Le Bourvellec).

1 Present address: University of California at Davis, Department of Viticulture and Enology, One Shields Ave., Davis, CA 95616-5270, USA. polyphenol interactions, concentrated on tannin and astringency perception. Three mechanisms can be jointly responsible for formation of polyphenol - cell-walls complexes. The first mechanism is non-covalent and consists in the adsorption of native and oxidised polyphenols to the cell-wall matrix, which will be detailed below. Two distinct mechanisms might lead to formation of covalent bonds, by reaction with cell wall polymers of polyphenols activated either (mechanism 2) by oxidation i.e. as quinones, (resulting primarily from action of polyphenoloxidase) or (mechanism 3 ) as carbocations, resulting from proanthocyanidin cleavage under acidic conditions, (Beart, Lilley, \& Haslam, 1985). The developments in polyphenol analysis and purification allowed to set up simple systems that can be used to quantify these interactions, to modify the conditions and investigate structure/affinity relationships for polyphenols and for polysaccharides (Le Bourvellec, \& Renard, 2005; Le Bourvellec, Bouchet \& Renard, 2005; Le Bourvellec, Guyot \& Renard, 2004a; Le Bourvellec et al., 2013; Renard, Baron, Guyot, \& Drilleau, 2001). These methods and 
similar approaches have been used also to quantify interactions of proanthocyanidins from grape to grape cell-walls, especially from the grape skin (Fournand et al., 2006; Bautista-Ortin, Molero, Marin, Ruiz-Garcia, \& Gomez-Plaza, 2015; Bindon, \& Kennedy, 2011, Bindon, Basic \& Kennedy, 2012, Bindon, Madami, Pendleton, Smith \& Kennedy, 2014). More recently physical methods such as isothermal titration calorimetry were used to gain insight in the mechanisms (Le Bourvellec, Watrelot, Ginies, Imberty, \& Renard, 2012; Watrelot, Le Bourvellec, Imberty, \& Renard, 2013, 2014). In the last few years, new topics were (1) the impact of thermal treatments (Le Bourvellec et al., 2011; 2013), with formation of covalent adducts between polyphenols and cell-walls, and (2) consequences, both technological and for polyphenol bioavailability.

Polyphenols are for the most part present in cell vacuoles. The most studied models for polyphenol - polysaccharide interactions are apples and grapes, both of which are rich in condensed tannins, chemically identified as proanthocyanidins. Apple and pear fruits have both high concentrations of polyphenols (up to $7 \mathrm{~g} / \mathrm{kg}$ fresh weight in the parenchyma of ripe fruit) and a relatively simple composition, notably in cider apples and perry pears. Procyanidins (flavan-3-ol oligomers and polymers) composed essentially of (-)-epicatechin are the main class in the fruit flesh of both apple and pear; their degree of polymerization vary between the cultivars and can be very high $(>100)$. The other classes are phenolic acids, mostly chlorogenic acid, and (in apple only) dihydrochalcones (phloretine glycosides), and monomeric flavan-3-ols, again mainly (-)-epicatechin. All of this makes these two fruit eminently suitable for isolation of well-defined fractions. In grape skin, polyphenols are characterized by the presence of proanthocyanidins of high degree of polymerization (typically mean degree of polymerization of 20-40), including galloylated subunits i.e. presence of both procyanidins and prodelphinidins (Mané et al., 2007), followed by anthocyanins in red varieties, and phenolic acids.

Plant cell-walls are a complex, porous polysaccharidic material. In fruits and vegetables, they can be described by the type I model of Carpita \& Gibeaut (1993) as composed of three interpenetrating but not interconnected networks: a cellulose/xyloglucan framework ( $>500 \mathrm{~g} / \mathrm{kg}$ dry weight) is embedded in a pectin matrix (250-400 g/kg dw), locked into shape by cross-linked glycoproteins (extensin, about $10 \mathrm{~g} / \mathrm{kg} \mathrm{dw}$ ). The cell-wall compositions of apple or grapes are well studied, and correspond well to this model (Renard, Voragen, Thibault, \& Pilnik, 1991, 1990;; Vidal, Williams, O’Neil, \& Pellerin, 2001; Doco, Williams, Pauly, O’Neill, \& Pellerin, 2003; Vicens et al., 2009).

Consequences of polyphenol - polysaccharide interactions are far reaching in food processing. For example, they contribute to the selective extraction of polyphenols from apple to apple juice (Le Bourvellec, Le Quéré, \& Renard, 2007; Renard et al., 2011), and even more important from grape to must, as has been clearly shown by Bindon, Kennedy or Gomez-Plaza's works (e.g. BautistaOrtin et al., 2015; Bindon, Smith, \& Kennedy, 2010b, 2010a; Revelette, Barak, \& Kennedy, 2014; Ruiz-Garcia, Smith, \& Bindon, 2014). They also result in the major part of the so-called "unextractable polyphenols" (Perez-Jimenez, Diaz-Rubio, \& Sura-Calixto, 2013) or formation of pomaces, where cell-walls and (oxidised) polyphenols form a single material, with antioxidant capacity but also difficult re-extraction of the polyphenols and colours which may be detrimental for their valorisation as dietary fibers. They also modify the extractability of the cell-wall polymers (Le Bourvellec, Guyot, \& Renard, 2009), decrease their enzyme susceptibility and affect their fermentescibility (Aura et al., 2013; Bazzocco et al., 2008). This has also nutritional impacts: polyphenol - cell-wall interactions limit bioavailability of polyphenols, but they may contribute to the formation of bioactive phenolic metabolites in the gut.

Main results on mechanisms, affinities, and consequences of polyphenol (primarily procyanidins) - cell-wall interactions will be presented.

\section{Initial observations}

\subsection{In wine}

Most of the major solutes present in the grape berry at harvest contribute to wine composition in proportion to their amount in the fruit. However Hazak, Harbertson, Adams, Ho, and Bin Han (2005) found that only a fraction of the tannin present in berries was extracted during winemaking. Studies on the extraction of skin proanthocyanidins in model hydroalcoholic solution have shown that the extraction is incomplete, while only $23 \%$ of available skin proanthocyanidins recovered. The structural features of extracted and non-extracted proanthocyanidins in terms of composition and mean degree of polymerization (mDP) were quite different. Extracted proanthocyanidins had a lower mDP, while nonextracted proanthocyanidins had both higher $\mathrm{mDP}$ and subunit galloylation percentage (Fournand et al., 2006). Some of the nonextracted tannins were tightly bound to the insoluble matrix of the grape berry. Winemaking process also influences proanthocyanidins extraction from skin and seed grapes. An increase of soluble solids and a decrease of the rate of proanthocyanidins extraction were observed with a reduction in grape berry crushing during fermentation (Cerpa-Calderon \& Kennedy, 2008). It was suggested that the extraction of phenolic compounds was similar with a diffusion-controlled process influenced by temperature, cell permeability, ethanol concentration. During maceration, the application of pectin-degrading enzymes enhances the degradation of pectic fractions from grape cell-walls and leads to an increase of proanthocyanidins extraction (Ducasse et al., 2010). As maceration duration increases, concentration of (-)-epicatechin-3-O-gallate subunits (present in higher proportion in seed proanthocyanidins) increased and (-)-epigallocatechin subunit (from skin) decreased, as well as proanthocyanidins molecular size (Yacco, Watrelot, \& Kennedy, 2016). This suggested that seed proanthocyanidin extraction increased with the time of maceration but might also be explained by binding of the proanthocyanidins to yeasts or grape biomass during fining on lees (Rodrigues, Ricardo-Da-Silva, Lucas, \& Laureano, 2013). These findings have significant implications for wine production and have the potential to explain the discrepancies often observed between total proanthocyanidin concentration in grape tissues and the quantity of proanthocyanidins in wine (Fournand et al., 2006). In fact, the quantities found in wine are frequently lower than expected and show large differences depending on variety (Busse-Valverde, Bautista-Ortin, GomezPlaza, Fernandez-Fernandez, \& Gil-Nunoz, 2012; 2010).

\subsection{In apple juice}

A similar phenomenon has also been observed to occur during apple juice processing and cider production. Studies, carried out at the Unité de Recherches Cidricoles, have highlighted a discrepancy, both quantitative and qualitative, between procyanidin concentrations in the apples and juices (Guyot, Marnet, Sanoner, \& Drilleau, 2001, 2003) (Fig. 1). Although in apples the main polyphenol class is that of procyanidins, in apple juice phenolic acids become much more important. This was especially obvious for apples of Guillevic (GU) variety, containing primarily procyanidins of high degree of polymerization (DPn of 63) (Renard et al., 2011) (Fig. 1). Apple cells are disrupted during crushing and pressing steps to produce apple juice. Apple procyanidins can be selectively 
Apples

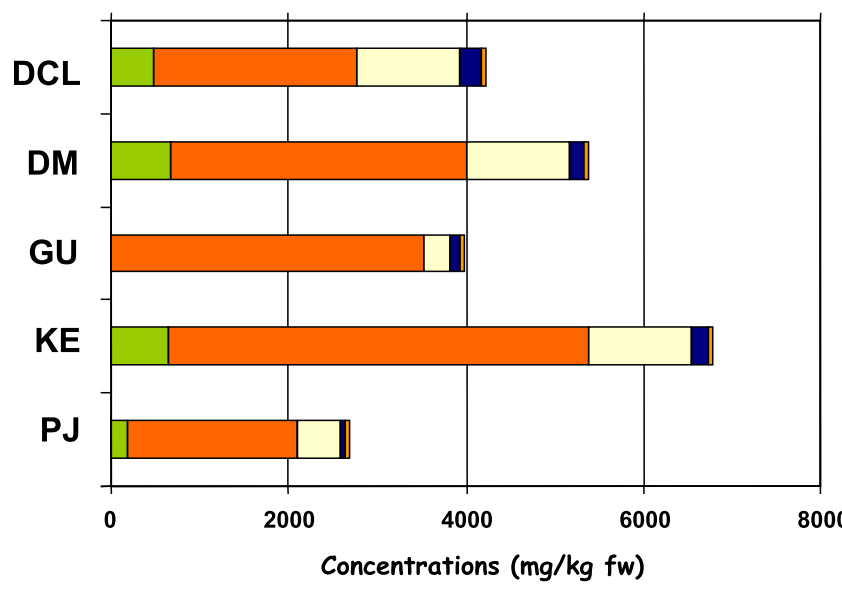

Juice

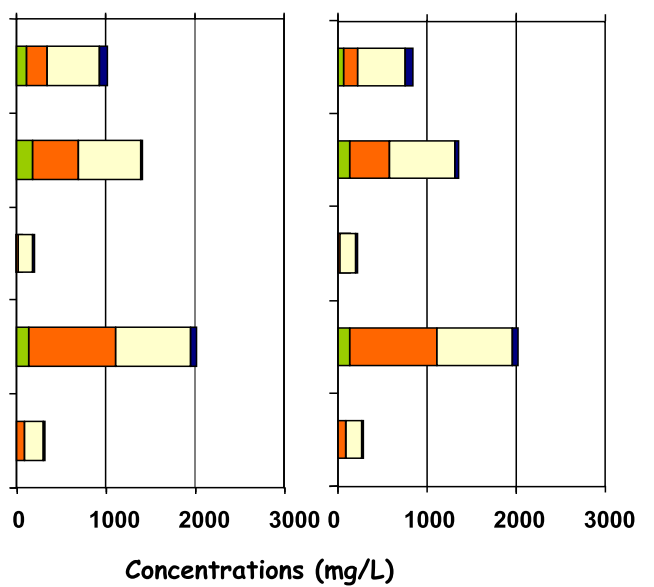

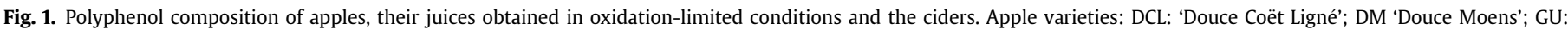

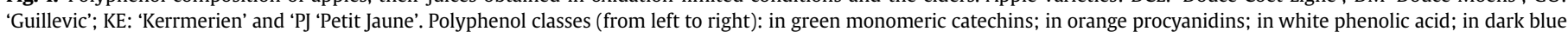
dihydrochalcones, and in yellow flavonols. (For interpretation of the references to colour in this figure legend, the reader is referred to the web version of this article.)

absorbed by cell-wall material and/or be oxidised which results in lower procyanidins concentration in apple juice, with a lower degree of polymerization (Guyot et al., 2003). As it will be explained below, non-covalent interactions between cell-wall material and proanthocyanidins increased with highly polymerized proanthocyanidins. Monomeric catechins concentration slightly decreased from apple juice to cider, which is mainly attributed to the oxidation reactions during fermentation (Ye, Yue, \& Yuan, 2014).

\section{Quantification and kinetics}

In order to address the discrepancies observed and to investigate the phenomena leading to retention of polyphenols, and particularly proanthocyanidins, model experiments are carried out using purified proanthocyanidins and purified cell-walls material from grape or apple. They are put in contact, sometimes varying the concentrations and relative ratios, or the level of maturity of the fruit from which the cell-walls are extracted, and after incubation the free proanthocyanidins are separated by filtration and analysed quantitatively and qualitatively (depolymerization for subunit composition and degree of polymerization and gel permeation chromatography for size distribution determination). Thermodynamic parameters of interaction between pectic fractions and proanthocyanidins with various degree of polymerization have also been studied.

A fast absorption of procyanidins to the apple cell-walls is observed, with most absorption occurring in the first $5 \mathrm{~min}$, and maximum absorption levels being reached in $20 \mathrm{~min}$, whatever the degree of polymerization (Le Bourvellec et al., 2004a). This means that it occurs whenever tissue degradation happens. Similar levels are observed for pHs from 2 to 7 (Le Bourvellec et al., 2004a). Varying procyanidin concentrations are used to obtain binding isotherms, such as the ones pictured in Fig. 2, with procyanidins varying from 3 to 70 monomeric (-)-epicatechin units (Le Bourvellec, \& Renard, 2005). Similar results are obtained with grape proanthocyanidins. At low polyphenol concentrations, few proanthocyanidins remain free in solution, particularly for the higher degrees of polymerization. As the proanthocyanidin concentrations increase, the proportion of free proanthocyanidins increases, until a plateau is reached, particularly for the larger proanthocyanidins. The plateau levels are surprisingly high, as the

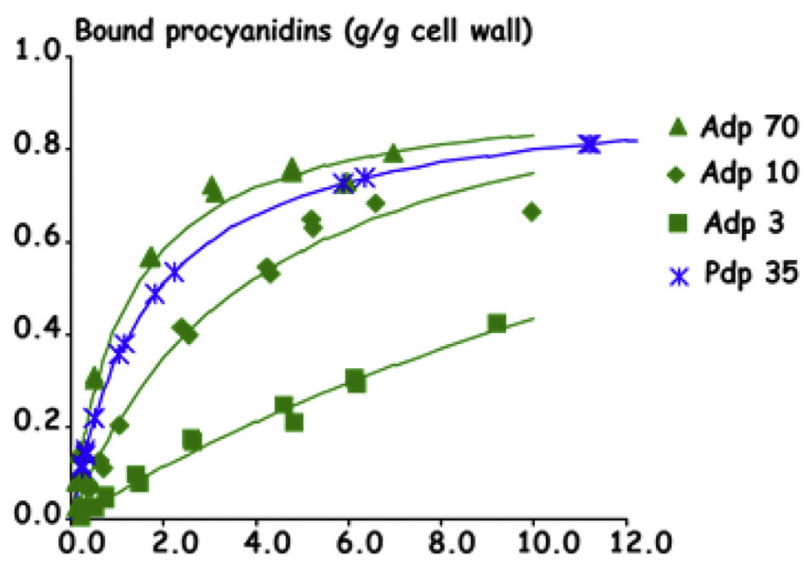

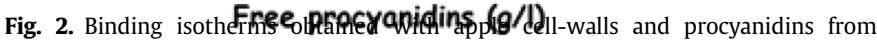
different degrees of polymerization. Redrawn from Le Bourvellec, \& Renard, 2005. Adp 70: procyanidins extracted from apple, $\mathrm{mDP}$ 70; Adp 10: procyanidins extracted from apple, mDP 10; Adp 3: procyanidins extracted from apple, mDP 3; Pdp 35: procyanidins extracted from pear, $\mathrm{mDP} 35$. Isotherms were established at $25^{\circ} \mathrm{C}$, in $0.05 \mathrm{~mol} / \mathrm{L}$ sodium acetate buffer $\mathrm{pH} 3.8$, and using a cell-wall concentration of $5 \mathrm{~g} / \mathrm{L}$.

weight of bound procyanidins reaches $80 \%$ of the initial cell-wall weight. The data can be fitted by Langmuir isotherm formulation, allowing calculation of affinity constants and saturation levels.

\section{Mechanisms}

\subsection{Non-covalent interactions}

As regards the nature of these associations, the question of the mechanism(s) of the association between procyanidins and cellwalls was approached by using physicochemical parameters or compounds that have the capacity to inhibit or to increase ionic interactions, hydrophobic interactions or hydrogen bonding (Le Bourvellec et al., 2004a; Renard et al., 2001). Complex formation between procyanidins and cell-walls is not affected by $\mathrm{pH}$ in the range 2.2-7. Electrostatic or ionic interactions thus do not appear to play any part in the association between procyanidins and cell- 
walls. Adsorption increases with increasing ionic strength, suggesting the presence of hydrophobic interactions, and decreases with increasing temperature, indicating hydrogen bonding. Procyanidins adsorption is also decreased by urea, dioxane, and ethanol (Le Bourvellec et al., 2004a; Renard et al., 2001). Washing procyanidins cell-wall complexes with $8 \mathrm{M}$ urea or an acetone:water 60:40 solution, results in total re-extraction of the procyanidins while washing with buffer leads only to partial re-extraction, and adding $\mathrm{NaCl}$ actually decreases this re-extraction. This indicated that the adsorption mechanism seems to involve the establishment of a number of weak energy non-covalent bonds, more precisely a combination of hydrogen bonds and hydrophobic interactions (Le Bourvellec et al., 2004a; Renard et al., 2001). Plumb, De Pascual-Teresa, Santos-Buelga, Cheynier, and Williamson (1998) also showed that the hydrophobic character of proanthocyanidins increases with the degree of polymerization as well as the galloylation. Using isothermal titration calorimetry, pectic fractions with different degree of methylation were titrated by apple procyanidins with two degrees of polymerization. High affinities have been observed between highly methylated (DM 70) homogalacturonans (galacturonic acid chain from pectin) and highly polymerized procyanidins (DP 30) through hydrophobic interactions (Watrelot et al., 2013). It was suggested that hydrophobic interactions occur between methyl groups of pectic fraction and dihydropyran heterocycles (C-ring) of procyanidins. Hydrogen bonds, mainly driven by enthalpy, have also been shown between some pectic hairy regions and procyanidins, but might be more induced by conformational changes of compounds in solution (Watrelot et al., 2014). Proanthocyanidins are known to self-associate in solution, which creates a limitation of association with cell-wall and/or protein, as it was suggested by the variation of association of pectins and proteins to immobilized procyanidins (Watrelot et al., 2016).

In some respects proanthocyanidin - polysaccharide complexation is similar to proanthocyanidin-assisted aggregation of proteins, that is they are mediated by hydrogen bonds and hydrophobic interactions; however there is a capital difference between the two phenomena. Proanthocyanidins interact with proteins in a series of steps. Initially there is the binding of proanthocyanidin to protein by hydrogen bonds and hydrophobic interaction; these initial, soluble protein-proanthocyanidin complexes then form aggregates by self-association and finally precipitate via colloid formation (Jobstl, O'Connell, Fairclough, \& Williamson, 2004; McRae, Falconer, \& Kennedy, 2010). Protein compactness is enhanced within the aggregates. On the contrary, interactions of proanthocyanidins with cell-walls appear to be a rapid, direct binding event. Polysaccharides do not collapse nor form closely packed aggregates in the presence of proanthocyanidins, but create either loose oligomers or microgels that are even less compact than single polysaccharide coils (Carn et al., 2012). The difference is easily observable already by moderate centrifugation, where proanthocyanidin-protein micelles are found in the pellet, while proanthocyanidin-polysaccharide complexes remain stable even at ultracentrifugation of $8 \times 10^{5} \mathrm{~g}$. The explanation of this difference is in the physical properties of proteins and polysaccharides. So, proanthocyanidins - polysaccharides associations are governed by the same mechanisms as proanthocyanidinprotein interactions but with different kinetics and colloidal consequences.

\subsection{Covalent interactions}

Unequivocal evidence for formation of covalent bonds between polyphenols and polysaccharides is difficult to find. The ideal proof would be formation in vitro of covalent complexes followed by degradation of /ythe polysaccharide to ayield : a / well idefined compound, as is successfully possible for the presence of ferulic acids bound to cereal or sugar-beet cell-walls (Ralet, Thibault, Faults, \& Williamson, 2004; Saulnier \& Thibault, 1998). However this has not been possible so far, so that existence of these bonds can only be inferred from the existence of irreversible complexes of polyphenols and polysaccharides. A good example of formation of irreversible complexes between polyphenols and polysaccharides is the formation of pomace during juice extraction. In pomaces high levels of insoluble phenols are present and their separation from the polysaccharides becomes very difficult; polyphenolpolysaccharide complexes are thus frequently observed. Covalent interactions could be mediated by procyanidins oxidation reactions, for example during enzymatic browning. In presence of molecular oxygen when cells are disrupted, polyphenoloxydases (PPO) are able to catalyse monophenols hydroxylation in orthodiphenols through a reversible process, then oxidize these orthodiphenols in ortho-quinones (Rouet-Mayer, Ralambosoa, \& Philippon, 1990). The highly reactive ortho-quinones can, depending on the relative redox values of the polyphenol - quinone couples, transfer their oxidation to other polyphenols. Proanthocyanidins are not substrates of PPO (Goodenough \& Lea, 1979; Le Bourvellec, Le Quéré, Sanoner, Drilleau, \& Guyot, 2004b), but they can be converted into corresponding ortho-quinones by coupled oxidation/reduction involving caffeoylquinic acid ortho-quinones. Ortho-quinones are highly electrophilic, which allows nucleophilic addition of polyphenols or proteins and leads to dimer formation and covalent bonds between polyphenols and other compounds (Trombley, Loegel, Danielson, \& Hagerman, 2011). A systematic investigation was carried out in Le Bourvellec et al. (2009), where purified apple cell-walls, devoid of polyphenols, were put in contact with procyanidins in the absence or presence of caffeoylquinic acid quinones (as drivers of oxidation). Clearly presence of the caffeoylquinic acid quinones enhances binding of the procyanidins to the apple cells walls, as observed gravimetrically. The bound procyanidins become partially resistant to solvolysis, while pectin extractability decreases.

Retention of procyanidins occurs also after plant tissue disruption induced by thermal treatments. This was evidenced in analysis of apple purees and pear wedges, where high concentrations of procyanidins are detected in the solid products (apple puree particles, pear wedges) (Renard, 2005a; Le Bourvellec et al., 2011, 2013). In pears submitted to prolonged thermal treatment a further phenomenon was observed with apparition of a pink discolouration. It can also appear during the processing of other fruits such as quinces (Hamauzu, Kume, Yasui, \& Fujita, 2007) apples, bananas, gooseberries, guavas, and peaches (Adams \& Brown, 2007). The appearance of pink discolouration depends on various factors, such as $\mathrm{pH}$, temperature, treatment time, type of can used, and storage. However, the main processing factors leading to increased discoloration are excessive heating and delayed cooling of the cans (Adams \& Brown, 2007). This pink discolouration could be replicated in model solutions or in cell-wall - procyanidin adducts, and was not re-extractable with solvent or with enzymes, leading us to suspect formation of covalent adducts (Fig. 3). This phenomenon is poorly understood. A possible mechanism is chemical depolymerisation of procyanidins, also referred to as condensed tannins, under hot acidic conditions during processing, and their conversion into anthocyanidins (Bate-Smith, 1954). In hot acidic conditions, the interflavan bond, which is relatively fragile, is cleaved. In this process, terminal units are released as free flavan-3ols, whereas intermediate C-4 carbocations are formed from the extension units. These carbocations are very reactive and can either give anthocyanidins by autoxidation (Bate-Smith, 1954) or react with nucleophilic compounds such as cell-wall polymers to form covalent bonds as in thecase of protein (Beart et al., 1985). Mass 


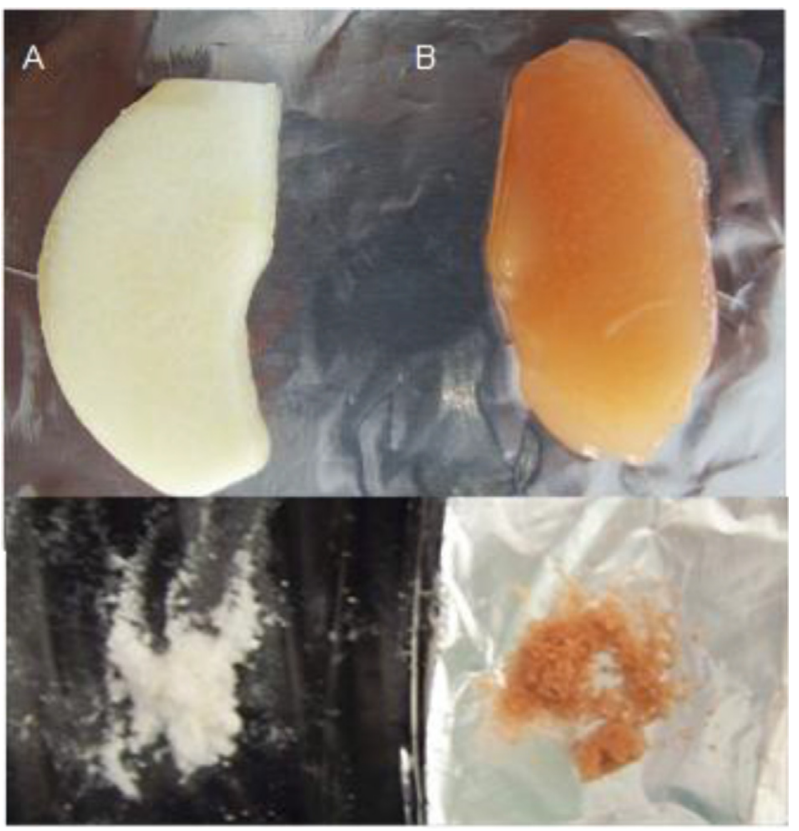

Fig. 3. Pink discoloration in William pear after prolonged heat treatment in acidic conditions: colour effects. A: raw pear; B: pear were processed at $95^{\circ} \mathrm{C}$ and $\mathrm{pH} 2.7$ for $418 \mathrm{~min}$ (Le Bourvellec et al., 2013). Powders are cell-walls isolated from the processed pears by the phenol-buffer method described by Renard (2005b). (For interpretation of the references to colour in this figure legend, the reader is referred to the web version of this article.)

spectrometry identification of thioacidolysis products allowed to identify formation of cyanidin and (-)-epicatechin-cyanidin dimer, probably through acid cleavage of the interflavanic bond followed by oxidation, as described by Beart et al. (1985).

\section{Structure activity relationships}

Since plant cell-wall contains multiple components, the interactions between proanthocyanidins and cell-walls are likely to be dependent on both the chemical characteristics of proanthocyanidins such as molecular structure and weight, and the physical properties and chemical composition of the cell-walls (Hanlin, Hrmova, Harbertson, \& Downey, 2010; Le Bouvellec \& Renard, 2012). Associations between proanthocyanidins and cell-walls could be related to a tanning effect as in the case of proanthocyanidins - protein interactions (McManus et al., 1985). This tanning effect is a function of both the presence of functional groups able to form hydrogen bonds and hydrophobic interactions, and of the molecular weights, i.e. the size of the polyphenol (McManus et al., 1985). Cell-walls contain hydroxyl groups as well as aromatic and glycosidic oxygen atoms that have the ability to form hydrogen bonds and hydrophobic interactions. Proanthocyanidins also contain hydroxyl groups as well as aromatic rings.

\subsection{Polysaccharides}

Cell-wall structure and composition have been shown to influence the association with proanthocyanidins. In particular for grape cell-wall, proanthocyanidins adsorption was consistently lower for skin cell-wall than for flesh (Bindon, Smith, \& Kennedy, 2010a, 2010b, Bindon \& Kennedy, 2011). Key structural differences that reduce proanthocyanidins adsorption in skin cell-walls by comparison to flesh cell-walls are: endogenously higher concentrations of insoluble proanthocyanidins, presence of lignin, towercell-wall bound protein. These differences may confer reduced flexibility and porosity of skin cell-walls relative to flesh cell-walls (Bindon et al., 2010b, 2012). Ripening of grape skin cell-walls also enhances adsorption of proanthocyanidins especially those of high molecular mass (Bindon et al., 2012, 2014; Castro-Lopez, GomezPlaza, Ortega-Regules, Lozada, \& Bautista-Ortin, 2016). The onset of veraison is characterized by skin cell-walls that showed a low level of proanthocyanidins adsorption, especially of those of high molecular mass. As ripening progresses skin cell-wall isolates show an increase of the retention of proanthocyanidins (Bindon et al., 2012). Slight chemical changes that occur in the cell-wall material composition are accompanied by physical and spatial changes in cell-walls during maturation, especially an increase of porosity. This increased cell-wall porosity would facilitate penetration of large proanthocyanidins molecules into a more open cell-wall network (Le Bourvellec et al., 2012) and explain the highest adsorption of tannins of higher molecular weight in cell-walls from ripe grape skins. In a same manner, harsh drying of apple cell-walls at $100{ }^{\circ} \mathrm{C}$ was shown to reduce their surface area due to a decrease in porosity and an alteration of the 3-dimensional structure of the cell-wall, decreasing the affinity constant of procyanidins to the apple cell-walls (Le Bourvellec, \& Renard, 2005). Modification of the composition of cell-walls by the selective removal of galacturonan-rich pectin fraction of apple cell-walls by boiling (Le Bourvellec et al., 2012) or enzymatic treatment (Renard et al., 2001) or of grape cell-walls by chelating agent (Ruiz-Garcia et al., 2014) decreases the adsorption of proanthocyanidins by cellwalls. Nevertheless, a high binding capacity of cell-wall hemicellulosic fractions for proanthocyanidins is retained, although lower than observed when pectins are present (Le Bourvellec et al., 2012; Ruiz-Garcia et al., 2014). Using purified and commercial proanthocyanidins and cell-wall material from different origin, Bautista-Ortin et al. (2015) have shown that cell-walls with higher pectin content and a more flexible conformation have a higher binding capacity. Binding isotherms carried out on model polysaccharides also indicate that the affinity of procyanidins is greatest for pectins followed by xyloglucan, and lowest for cellulose (Le Bourvellec et al., 2005). This higher affinity with pectins may be due to the formation of a three-dimensional gel-like network, forming hydrophobic pockets, able to encapsulate proanthocyanidins. A high affinity of procyanidins for highly methylated galacturonans, the main component of pectins, is confirmed by the modulation of extraction of polysaccharide after procyanidins binding and by isothermal titration calorimetry (Le Bourvellec et al., 2009; Le Bourvellec et al., 2012). Moreover, increasing degree of methylation of homogalacturonan and type I rhamnogalacturonans was noted to enhance procyanidins binding (Watrelot et al., 2013, 2014), in comparison to non-methylated homogalacturonans and other pectic hairy regions (type II rhamnogalacturonans). Neutral sugars of pectic hairy regions can adopt specific conformations in solution, leading to variation of association with procyanidins. Citrus pectins containing more type I rhamnogalacturonans have higher affinity with immobilized procyanidin dimer than apple pectins (Watrelot et al., 2016).

\subsection{Proanthocyanidins}

The extent and strength of proanthocyanidins cell-wall associations will also depend both on concentrations and on the characteristics of the proanthocyanidins, including their molecular mass, degree of galloylation and/or the stereochemistry of their molecules. In general, proanthocyanidins with higher degree of polymerization and degree of galloylation are selectively adsorbed by cell-wall (Renard et al., 2001; Le Bourvellec et al., 2004a). Studies on interactions between proanthocyanidins and cell-wall material 
from flesh and skin of grape have shown that fining with cell-walls material is size-based (Bindon et al., 2010a). Gel permeation chromatography has shown that the role of proanthocyanidins galloylation can be explained by the variation in size of galloylated material, as opposed to specific selectivity of galloylated proanthocyanidins. As observed using isothermal titration calorimetry, the higher the degree of polymerization, the higher the association and aggregates formation with pectic fractions was (Watrelot et al., 2013) (Fig. 4). An exception to the selective binding of large-size proanthocyanidins has been found for very high molecular mass proanthocyanidins ( $>15,000 \mathrm{~g} / \mathrm{mol}$ ) from skin of red grapes, which appear to be excluded from bindings when cell-wall porosity is low (Bindon et al., 2010a, 2012, 2014; Bindon \& Kennedy, 2011). Proanthocyanidin activity determined by the thermodynamics of interaction between red wine proanthocyanidins and a hydrophobic surface was more correlated to molecular mass than to the degree of polymerization (Yacco et al., 2016). The constitutive subunits of proanthocyanidins can induce variations of conformation and also of polysaccharide interactions. Proanthocyanidins comprising (+)-catechin as extension units had higher affinity to cell-wall polysaccharides than proanthocyanidins mainly with (-)-epicatechin (McManus et al., 1985). Interactions with cell-walls are modulated by flavan-3-ol subunit composition, the stereochemistry of which might lead to changes in proanthocyanidins conformation (Le Bourvellec et al., 2004a), a more open and flexible conformation facilitating formation of hydrogen bonds and hydrophobic interactions. The extent of proanthocyanidins binding on cell-wall also depends on the concentration. An increase of the polyphenol concentration leads to more proanthocyanidin bound per cell-wall mass unit (Renard et al., 2001; Le Bourvellec, \& Renard, 2005).

\section{Consequences}

\subsection{Technological consequences}

The quantification of adsorption of procyanidins on cell-wall materials was used to develop a model, on the basis of the Langmuir isotherm formulation and a factorial experimental design, to predict the extraction of procyanidins from apple to juice in absence of oxygen (Le Bourvellec et al., 2007). The parameters that influence the adsorption are the concentration and molecular weight of the procyanidins, the ionic strength of the solution, the temperature at pressing, and the apple cell-wall concentration. From a technological point of view, the two factors ionic strength and temperature are relevant for transfer of polyphenols from apple must. There are limited variations in the ionic strength which could be calculated for apples from their acidity and known ion composition. However, they occur in the part of the ionic strength range where effects are most pronounced. For the cider-maker, this parameter is fixed by the apple, but could be modulated using different apple cultivars. On the other hand, the temperature of pressing, which can vary from 5 to $20^{\circ} \mathrm{C}$, will had an influence on the transfer of apple polyphenols to must, and can be modulated by the users. This effect of temperature was validated in apple pressing, for temperatures from $4{ }^{\circ} \mathrm{C}$ to $25^{\circ} \mathrm{C}$ : while, in absence of oxidation, extraction is almost quantitative for hydroxycinnamic acids at all temperatures, there is an impact on transfer for all flavan-3-ols, particularly procyanidins (Renard et al., 2011), with about $30 \%$ higher extraction at $25{ }^{\circ} \mathrm{C}$ than at $4{ }^{\circ} \mathrm{C}$ (Table 1 ).

The ability of cell-walls to form complexes with proanthocyanidins makes them an interesting object of study for their possible use as new fining agents as an alternative to animal proteins in winemaking. Such studies were initiated by Bindon and Smith (2013) and Guerrero, Smith, and Bindon (2013), who studied the fining action of insoluble fibers prepared from apple flesh and different grape sources and compared them with commercial proteins, reporting that grape fibers may be considered as alternative fining agents for red wine. Proteins and fibers from purified cell-wall of fresh grape and apple fruits and pomaces present a high affinity for proanthocyanidins structures and especially high molecular mass (Bautista-Ortin et al., 2014; Bindon \& Smith, 2013; Guerrero et al., 2013), while selectivity for proanthocyanidins by subunit composition is variable between treatments, but differences are minor (Bindon \& Smith, 2013). Proanthocyanidins removal by cell-wall materials requires a higher dose to achieve a fining effect comparable with proteins (Bindon \& Smith, 2013). Moreover, from all sources of fibers tested, the purified cell-wall of

\section{Table 1}

Procyanidins and chlorogenic acid concentrations $(\mathrm{mg} / \mathrm{L})$ in apple juices prepared under anaerobic conditions as a function of temperature. CQA: chlorogenic acid; Procya: procyanidins. Data from Renard et al., 2011.

\begin{tabular}{|c|c|c|c|c|c|c|}
\hline & \multicolumn{2}{|c|}{ Douce Moens } & \multicolumn{2}{|c|}{ Guilllevic } & \multicolumn{2}{|c|}{ Kermerrien } \\
\hline & CQA & Procya & CQA & Procya & CQA & Procya \\
\hline $4^{\circ} \mathrm{C}$ & 1099 & 853 & 80 & 121 & 862 & 1349 \\
\hline $11^{\circ} \mathrm{C}$ & 1158 & 986 & 82 & 107 & 1000 & 1520 \\
\hline $18{ }^{\circ} \mathrm{C}$ & 1213 & 1067 & 85 & 132 & 950 & 1821 \\
\hline $25^{\circ} \mathrm{C}$ & 1311 & 1396 & 96 & 146 & 990 & 1842 \\
\hline
\end{tabular}

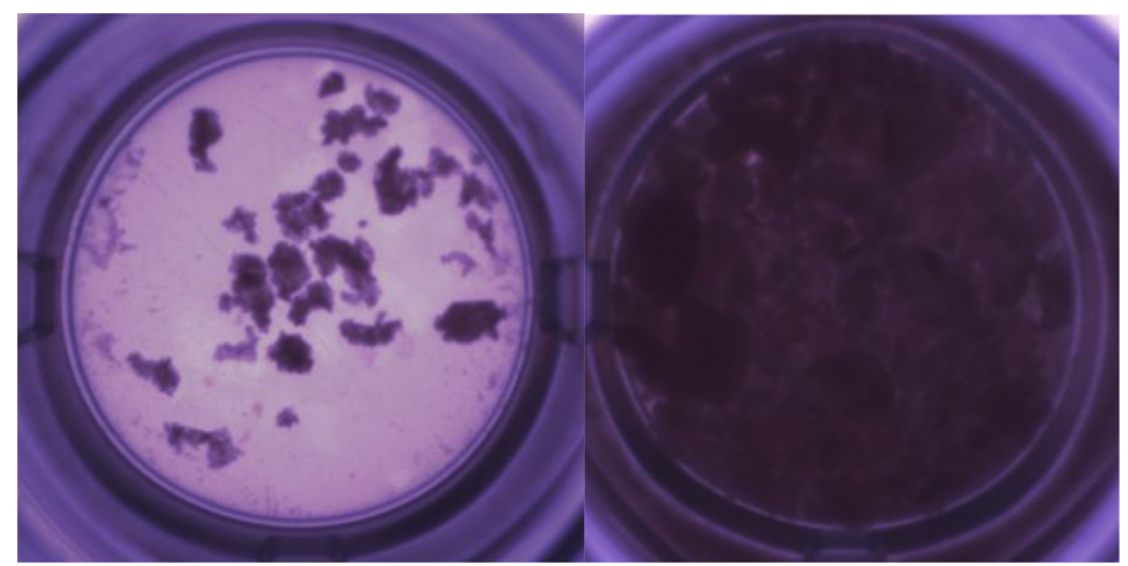

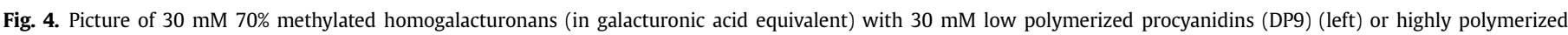
procyanidins (DP30) (right) (in (-)-epicatechin equivalent). 
fresh grape and apple fruits show a greater dose effect on adsorption of proanthocyanidins than the corresponding extracts from pomace (Bindon \& Smith, 2013). The fact that most fibers selectively remove proanthocyanidins of higher molecular mass is important as large-size proanthocyanidins are known to be a stronger driver of astringency. However, grape fibers not only reduce proanthocyanidins but also reduce anthocyanins, total phenolics and wine colour density (Guerrero et al., 2013). For further development of these alternative fining agents some technological aspects such as the amount of lees formed during their use and their role in wine composition and flavour (Bautista-Ortin et al., 2014; Bindon \& Smith, 2013; Guerrero et al., 2013) need to be assessed. Similar observations have been reported in cider processing: in a study on the sensory characteristics of cider, Symoneaux et al. (2015) used water-extracted apple pomace to decrease procyanidin content and degree of polymerization in cider, obtaining a product with lower astringency. Moreover, the use of enzymes during winemaking process leads to modifications of grape polysaccharides. Those enzymes lead to a decrease of methylated pectins and neutral sugars and to an increase of galacturonic acid and type II rhamnogalacturonans (Doco, Williams, \& Cheynier, 2007). A higher extraction of proanthocyanidins has been observed during the winemaking process due to cell-wall degradation during maceration stage.

Interactions with solubilized cell wall polymers may on the other hand favor retention of proanthocyanidins as soluble complexes in the liquid phase. Indeed Riou, Vernhet, Doco, \& Moutounet, 2002 observed that the different polysaccharides, while they do not modify initial aggregation of tannins, influence further particle size evolution. Arabinogalactan proteins and mannoproteins notably may decrease tannins aggregation (PoncetLegrand, Doco, Williams, \& Vernhet, 2007; Riou, Vernhet, Doco, Moutounet, 2002).

\subsection{Nutritional consequences}

The binding of proanthocyanidins to cell-wall components can have significant effects on the release of phenolic compounds from the food matrix for potential absorption in the human gastrointestinal tract (i.e. bioaccessibility). It is becoming increasingly clear that the biological effects of proanthocyanidins should not be attributed to the native compounds present in foods, but rather to their metabolite products in the colon, which are diverse phenolic acids (Williamson \& Clifford, 2010; Del Rio, Costa, Lean, \& Crozier, 2010, Del Rio et al., 2013). These colonic metabolites are produced during fermentation by the colonic microflora of native substances and are strongly absorbed. Proanthocyanidins associated with cell-wall are poorly bioavailable in the upper intestine (Donovan et al., 2002) and reach the colon, where they become fermentable substrates for bacterial microflora, which convert them into active metabolites (Bazzocco et al., 2008). Evidence of the effect of food matrix and noncovalent interactions between procyanidin and cell-wall on the metabolism of procyanidins by human microflora has been recently found (Aura et al., 2013; Bazzocco et al., 2008). Fermentation studies were performed by colon microbiota in in vitro digestion model using freeze-dried apples, procyanidins extracts from these apples and freeze-dried cider made from the same apples. The conversion rate of procyanidins to known microbial metabolites is much lower with isolated procyanidins than with whole fruit, the larger polymers being also less metabolized than the smaller ones. The larger molecules are able to inhibit both the microbial conversion of procyanidins to phenolic acids and of carbohydrate to short-chain fatty acids, but this inhibition is reduced in the presence of the food matrix (Aura et al., 2013; Bazzocco et al., 2008). The inhibitory effect of procyanidins is dose-dependent (Aura et al., 2013; Bazzocco et al., 2008). It seems that cell-wall acts as a nutrient for colonic microorganisms responsible for the conversion of procyanidins into active metabolites.

\section{Conclusion and future trends}

Interactions between polyphenols, and particularly proanthocyanidins, and polysaccharides have now been convincingly demonstrated. They are fast and spontaneous, which means that they occur systematically in fruit and vegetable processing. The binding is due to a combination of hydrogen bonds and hydrophobic interactions, and is favoured by increased ionic strength and decreased temperature. Higher affinities are found for proanthocyanidins of high degree of polymerization. Within the cell-walls, higher affinities for pectins are confirmed in solution with various structural pectin parts using isothermal titration calorimetry. Another parameter is the physical state of the cell-walls, with a major impact of porosity and flexibility.

These interactions and their variations can be incurred during food processing, for example as a function of maturation degree of fruit. They can also be used and manipulated: enzyme application and maceration of grapes modify the final phenolic concentration of wines, cell-walls or pomaces have been proposed as finding agents, and modification of pressing temperature modulates cider astringency.

Growing evidence indicates that the biological effects of proanthocyanidins should be attributed to their colonic metabolites rather than to the native proanthocyanidins present in foods. Proanthocyanidins associated with plant cell-walls are poorly bioavailable in the upper gut and reach the colon where they become fermentable substrates for the commensal microbiota, which converts them into readily absorbable metabolites.

Further research needs which can be identified at this point are:

- Improved understanding and quantification of the impact of the proanthocyanidin - cell-wall interactions in food processing, notably in juice extraction, as a function of the state of cell-walls and processing options;

- Understanding the nutritional consequences of the proanthocyanidin - cell-wall complexes in the colon: does the formation of complexes modify the fermentation patterns (of either partner), which are the enzymes and the bacteria involved;

- More fundamental understanding of the type of interactions and the behaviour of the proanthocyanidins in presence of both polysaccharides and proteins;

- Demonstrating convincingly the existence of covalent bonds between proanthocyanidins and cell-walls by isolation and structural elucidation of molecules (or fragments), and by designing experimental models able to replicate these adducts.

\section{Acknowledgements}

The work leading to this review was supported by funding from the European Union's Seventh Framework Programme for research, technological development and demonstration under grant agreement $\mathrm{n}^{\circ}$ FP7-222654 (DREAM), and from Région Bretagne and Pays de la Loire under grant agreement CIPOLINA. The authors thank Drs. J.F. Drilleau, S. Guyot, A. Baron, J.M. Le Quéré, D. Fournand, A. Imberty, S. Quideau, D. Deffieux, K. Bindon, A. Mierczynska-Vasilev, J. Kennedy and P. Mosoni for fruitful discussions through the years. 


\section{References}

Adams, J. B., \& Brown, H. M. (2007). Discoloration in raw and processed fruits and vegetables. Critical Review in Food Science and Nutrition, 47, 319-333.

Aura, A. M. Mattila, I., Hijotijlainen, T., Gopalacharyulu, P.. Cheynier, V., Souquet, J. M., et al. (2013). Characterization of microbial metabolism of Syrah grape products in an in vitro colon model using targeted and non-targeted analytical approaches. European Journal of Nutrition, 52, 833-846.

Bate-Smith, E. C. (1954). Leuco-anthocyanins. 1. Detection and identification of anthocyanidins formed leuco-anthocyanins in plant tissues. Biochemical Journal, $58,122-125$.

Bautista-Ortin, A. B., Molero, N. Marin, F., Ruiz-Garcia, Y \& Gomez-Plaza, E. (2015) Reactivity of pure and commercial grape skin tannins with cell-wall material. European Food Research and Technology, 240, 645-654.

Bautista-Ortin, A. B., Ruiz-Garcia, Y., Marin, F., Molero, N., Apolinar-Valiente, R., \& Gomez-Plaza, E. (2014). Remarkable proanthocyanidins adsorption properties of Monastrell pomace cell-wall material highlight its potential use as an alternative fining agent in red wine production. Journal of Agricultural and Food Chemistry, 63, 620-633.

Bazzocco, S., Mattila, I., Guyot, S., Renard, C. M. G. C., Puupponen-Pimiä, R., \& Aura, A.-M. (2008). The factors affecting the conversion of apple polyphenols to phenolic acids and fruit matrix to short-chain fatty acids by human faecal microbiota in vitro. European Journal of Nutrition, 47, 442-445.

Beart, J. E., Lilley, T. H., \& Haslam, E. (1985). Polyphenol interactions.2. Covelant binding of procyanidins to proteins during acid-catalysed decomposition, observation on some polymeric proathocyanidins. Journal of the Chemical Society-Perkin Transactions, 2, 1439-1443.

Bindon, K. A., Basic, A., \& Kenedy, J. A. (2012). Tissue specific and developmental modificatios of grape cell-walls influence the adsorption of proanthocyanidins. Journal of Agricultural and Food Chemistry, 60, 9249-9260.

Bindon, K. A., \& Kennedy, J. A. (2011). Ripening-induced changes in grape skin proanthocyanidins modifies their interaction with cell-walls. Journal of Agricultural and Food Chemistry, 59, 2696-2707.

Bindon, K. A., Madami, S. H., Pendleton, P., Smith, P. A., \& Kennedy, J. A. (2014). Factor affecting skin tannin extractability in ripening grapes. Journal of Agricultural and Food Chemistry, 62, 1130-1141.

Bindon, K. A., \& Smith, P. A. (2013). Comparison of the affinity and selectivity of insoluble fibres and commercial proteins for wine proanthocyanidins. Food Chemistry, 136, 917-928.

Bindon, K. A., Smith, P. A. \& Kennedy, J. A. (2010a). Interaction between grape derived proanthocyanidins and cell-wall material. 1. Effect on proanthocyanidin composition and molecular mass. Journal of Agricultural and Food Chemistry, 58, $2520-2528$.

Bindon, K. A., Smith, P. A., \& Kennedy, J. A. (2010b). Interaction between grape derived proanthocyanidins and cell-wall material. 1. Implacation for vinification. Journal of Agricultural and Food Chemistry, 58, 10736-10746.

Busse-Valverde, N. Bautista-Ortin, A. B., Gomez-Plaza, E FernandezFernandez, J. L., \& Gil-Nunoz, R. (2012). Influence of skin maceration time on the proanthocyanidin content of red wines. European Food Research and Technology, 235, 1117-1123.

Busse-Valverde, N., Gomez-Plaza, E., Lopez-Roca, J. M., Gil-Nunoz, R., FernandezFernandez, J. L., \& Bautista-Ortin, A. B. (2010). Effect of different oenological practices on skin and seed proanthocyanidins in three varietal wines. Journal of Agricultural and Food Chemistry, 58, 11333-11339.

Carn, F., Guyot, S., Baron, A., Perez, J., Buhler, E., \& Zanchi, D. (2012). Structural properties of colloidal complexes between condensed tannins and polysaccharide hyaluronan. Biomacromolecules, 13, 751-759.

Carpita, N. C., \& Gibeaut, D. M. (1993). Structural models of primary cell walls in flowering plants : Consistency of molecular structure with the physical properties of the walls during growth. The Plant Journal, 3, 1-30.

Castro-Lopez, L. R., Gomez-Plaza, E., Ortega-Regules, A., Lozada, D., \& BautistaOrtin, A. B. (2016). Role of cell-wall deconstructinfg enzymes in the proanthocyanidins-cell-wall adsorption-desorption phenomena. Food Chemistry, 196, 526-532.

Cerpa-Calderon, F. K., \& Kennedy, J. A. (2008). Berry integrity and extraction of skin and seed proanthocyanidins during red wine fermentation. Journal of Agricultural and Food Chemistry, 56(19), 9006-9014.

Del Rio, D. Costa, L. G. Lean, M. E. J. \& Crozier, A. (2010). Polyphenols and health: What compounds are involved? Nutrition, Metabolism and Cardiovascular Disease, 20, 1-6.

Del Rio, D., Rodriguez-Mateos, A., Spencer, J. P. E., Tognolini, M., Borges, G., \& Crozier, A. (2013). Dietary (Poly)phenolics in human Health: Structures, bioavailability, and evidence of protective effects against chronic diseases. Antioxidants \& Redox Signaling, 18, 1818-1892.

Doco, T. Williams, P., \& Cheynier, V. (2007). Effect of flash release and pectinolytic enzyme treatments on wine polysaccharide composition. Journal of Agricultural and Food Chemistry, 55(16), 6643-6649.

Doco, T., Williams, P., Pauly, M., O'Neill, M. A., \& Pellerin, P. (2003). Polysaccharides from grape berry cell-walls. Part II. Structural characterization of the xyloglucan polysaccharides. Carbohydrate Polymers, 53, 253-261.

Donovan, J. L., Manach, C., Rios, L., Morand, C., Scalbert, A., \& Remesy, C. (2002). Procyanidins are not bioavailable in rats fed a single meal containing a grapeseed extract or the procyanidin dimer B-3. British Journal of Nutrition, 87, 299-306.
Ducasse, M.-A., Canal-Llauberes, R.-M., de Lumley, M., Williams, P., Souquet, J.-M., Fulcrand, H., et al. (2010). Effect of macerating enzyme treatment on the polyphenol and polysaccharide composition of red wines. Food Chemistry, 118(2), 369-376.

Fournand, D., Vicens, A., Sidhoum, L., Souquet, J. M., Moutounet, M., \& Cheynier, V. (2006). Accumulation and extractability of grape skin tannins and anthocyanins at different advanced physiological stages. Journal of Agricultural and Food Chemistry, 54, 7331-7338.

Goodenough, P. W., \& Lea, A. G. H. (1979). Oidation of cider procyanidins by apple oxidase systems. Annual Report Long Ashton Research Station, 207-214.

Guerrero, R. F., Smith, P., \& Bindon, K. A. (2013). Application of insoluble fibers in the fining of wine phenolics. Journal of Agricultural and Food Chemistry, 61, $4424-4432$.

Guyot, S., Marnet, N., Sanoner, P., \& Drilleau, J. F. (2001). Direct thiolysis on crude apple materials for high-performance liquid chromatography characterization and quantification of polyphenols in cider apple tissues and juices. In L. Packer (Ed.), Methods in enzymology - flavonoïds and other polyphenols (pp. 57-70). New York, USA: Academic Press.

Guyot, S., Marnet, N., Sanoner, P., \& Drilleau, J.-F. (2003). Variability of the polyphenolic composition of cider apple (Malus domestica) fruits and juices. Journa of Agricultural and Food Chemistry, 51, 6240-6247.

Hamauzu, Y., Kume, C., Yasui, H., \& Fujita, T. (2007). Reddish coloration of Chinese quince (Pseudocydonia sinensis) procyanidins during heat treatment and effect on antioxidant and antiinfluenza viral activities. Journal of Agricultural and Food Chemistry, 55, 1221-1226.

Hanlin, R., Hrmova, M., Harbertson, J. F., \& Downey, M. (2010). Review : Condensed tannin and grape cell-wall interactions and their impact on tannin extractability into wine. Australian Journal of Grape and Wine Research, 16, 173-188.

Hazak, J. C., Harbertson, J. T., Adams, D. O., Ho, L., \& Bin Han, R. O. (2005). The phenolic components of grape berries in relation to wine composition. Actc Horticulturae, 689, 189-196.

Jobstl, E., O'Connell, J., Fairclough, J. P. A., \& Williamson, M. P. (2004). Molecula model for astringency produced by polyphenol/protein interactions. Biomacromolecules, 5, 942-949.

Le Bourvellec, C., Bouchet, B. \& Renard, C. M. G. C. (2005). Non-covalent interactions between procyanidins and apple cell-wall material. Part III : Study on model polysaccharides. Biochimica biophysica. Acta, 1675, 10-18.

Le Bourvellec, C., Bouzerzour, K., Ginies, C., Regis, S., Plé, Y., \& Renard, C. M. G. C. (2011). Phenolic and fiber composition of applesauce is close to that of apple flesh. Journal of Food Composition and Analysis, 24, 537-547.

Le Bourvellec, C., Gouble, B., Bureau, S., Loonis, M., Plé, Y., \& Renard, C. M. G. C. (2013). Pink discoloration of canned pears : Role of procyanidin chemical depolymerization and procyanidin/cell-wall interactions. Journal of Agricultural and Food Chemistry, 61, 6679-6692.

Le Bourvellec, C., Guyot, S., \& Renard, C. M. G. C. (2004a). Non-covalent interaction between procyanidins and apple cell-wall material Part 1: Effect of some environmental parameters. Biochimica Biophysica Acta, 1672, 192-202.

Le Bourvellec, C., Guyot, S., \& Renard, C. M. G. C. (2009). Interactions between polyphenols and cell-walls: Modification of polysaccharide extractability. Carbohydrate Polymers, 75, 251-261.

Le Bourvellec, C., Le Quéré, J. M., \& Renard, C. M. G. C. (2007). Impact of non-covalent interactions between condensed tannin and apple cell-walls: Elaboration of a quantitative model and its application to transfer from fruit to juice. Journal of Agricultural and Food Chemistry, 55, 7896-7904.

Le Bourvellec, C., Le Quéré, J. M., Sanoner, P., Drilleau, J. F., \& Guyot, S. (2004b). Inhibition of apple polyphenol oxidase activity by procyanidins and polyphenol oxidation products. Journal of Agricultural and Food Chemistry, 52, 122-130.

Le Bourvellec, C., \& Renard, C. M. G. C. (2005). Non-covalent interactions between procyanidins and apple cell-wall material. Part II : Quantification and impact of cell-wall drying. Biochimica Biophysica Acta, 1675, 1-9.

Le Bourvellec, C., Watrelot, A. A., Ginies, C., Imberty, A., \& Renard, C. M. G. C. (2012), Impact of processing on the non-covalent interactions between procyanidins and cell-walls. Journal of Agricultural and Food Chemistry, 60, 9484-9494.

Le Bouvellec, C., \& Renard, C. M. G. C. (2012). Interactions between polyphenols and Macromolecules: Quantification methods and mechanisms. Critical Reviews in Food Science and Nutrition, 52, 213-248.

Mané, C., Souquet, J. M., Ollé, D., Verriés, F., Véran, F., Mazerolles, G., et al. (2007). Optimization of simultaneous flavanol, phenolic acid, and anthocyanin extraction from grapes using an experimental design: Application to the characterization of champagne grape varieties. Journal of Agricultural and Food Chemistry, 55, 7224-7233.

McManus, J. P., Davis, K. G., Beart, J. E., Gaffney, S. H., Lilley, T. H., \& Haslam, E. (1985), Polyphenol interactions. Part I. Introduction; some observations on the reversible complexation of polyphenols with proteins and polysaccharides. Journal of the Chemical Society - Perkin Transactions II, 1429-1438.

McRae, J. M., Falconer, R., \& Kennedy, J. A. (2010). Thermodynamics of grape and wine tannin interaction with polyproline : Implication for red wine astringency. Journal of Agricultural and Food Chemistry, 58, 12510-12518.

Perez-Jimenez, J., Diaz-Rubio, M. E., \& Sura-Calixto, F. (2013). Non-extractable polyphenols, a major dietary antioxidant: Occurrence, metabolic fate and health effects. Nutrition Research Reviews, 26, 118-129.

Plumb, G. W., De Pascual-Teresa, S., Santos-Buelga, C., Cheynier, V., \& Williamson, G. (1998). Antioxidant properties of catechins and proanthocyanidins: Effect of polymerisation, galloylation and glycosylation. Free Radical Research, 29(4), 351-358. 
Poncet-Legrand, C., Doco, T., Williams, P., \& Vernhet, A. (2007). Inhibition of grape seed tannin aggregation by wine mannoproteins: Effect of polysaccharide molecular weight. American Journal of Enology and Viticulture, 58, 87-91.

Ralet, M. C., Thibault, J. F., Faults, C. B., \& Williamson, G. (2004). Isolation and purification of feruloylated oligosaccharides from cell-walls of sugar-beet ulp. Carbohydrate Research, 263, 227-241.

Renard, C. M. G. C. (2005a). Effects of conventional boiling on the polyphenols and cell-walls of pears. Journal of the Science of Food and Agriculture, 85(2), 310-318.

Renard, C. M. G. C. (2005b). Variability in cell wall preparations : Quantification and comparison of common methods. Carbohydrate Polymers, 60, 515-522.

Renard, C. M. G. C., Baron, A., Guyot, S., \& Drilleau, J.-F. (2001). Interactions between apple cell-walls and native apple polyphenols: Quantification and some consequences. International Journal of Biological Macromolecules, 29, 115-125.

Renard, C. M. G. C., Le Quéré, J. M., Bauduin, R., Symoneaux, R., Le Bourvellec, C., \& Baron, A. (2011). Modulating apple juices phenolic composition by manipulating the pressing conditions. Food Chemistry, 124, 117-125.

Renard, C. M. G. C., Voragen, A. G. J., Thibault, J.-F., \& Pilnik, W. (1990). Studies on apple protopectin I: Extraction of insoluble pectin by chemical means. Carbohydrate Polymers, $12,9-25$.

Renard, C. M. G. C., Voragen, A. G. J., Thibault, J.-F., \& Pilnik, W. (1991). Studies on apple protopectin iv: Apple xyloglucans and influence of pectin extraction treatment on their solubility. Carbohydrate Polymers, 15, 397-403.

Revelette, M. R., Barak, J. A., \& Kennedy, J. A. (2014). High-Performance liquid chromatography determination of red wine tannin stickiness. Journal of Agricultural and Food Chemistry, 62, 6626-6631.

Riou, V., Vernhet, A., Doco, T., \& Moutounet, M. (2002). Aggregation of grape seed tannins in model wine - effect of wine polysaccharides. Food Hydrocolloids, 16(1), 17-23.

Rodrigues, A., Ricardo-Da-Silva, J. M., Lucas, C., \& Laureano, O. (2013). Effect of winery yeast lees on touriga nacional red wine color and tannin evolution. American Journal of Enology and Viticulture, 64(1), 98-109.

Rouet-Mayer, M.-A., Ralambosoa, J., \& Philippon, J. (1990). Roles of o-quinones and their polymers in the enzymic browning of apples. Phytochemistry, 29(2), 435-440.

Ruiz-Garcia, Y., Smith, P. A., \& Bindon, K. A. (2014). Selective extraction of polysaccharide affects the adsorption of proanthocyanidin by grape cell-walls.
Carbohydrate Polymers, 114, 102-114.

Saulnier, L., \& Thibault, J. F. (1998). Ferulic acid and diferulic acids as components of sugar-beet pectins and maize bran heteroxylans. Journal of the Science of Food and Agriculture, 79, 396-402.

Symoneaux, R., Chollet, S., Patron, C., Bauduin, R., Le Quéré, J. M., \& Baron, A. (2015) Prediction of sensory characteristics of cider according to their biochemical composition: Use of a central composite design and external validation by cider professionals. LWT-Food Science and Technology, 61, 63-69.

Trombley, J. D., Loegel, T. N., Danielson, N. D., \& Hagerman, A. E. (2011). Capillary electrophoresis methods for the determination of covalent polyphenol-protein complexes. Analytical and Bioanalytical Chemistry, 401(5), 1527-1533.

Vicens, A., Fournand, D., Williams, P., Sidhoum, L., Moutounet, M., \& Doco, T. (2009). Changes in polysaccharide and protein composition of cell-walls in grape berry skin (cv. Shiraz) during ripening and over-ripening. Journal of Agricultural and Food Chemistry, 57, 2955-2960.

Vidal, S., Williams, P., O'Neil, M. A., \& Pellerin, P. (2001). Polysaccharides from grape berry cell-walls. Part I: Tissue distribution and structural characterization of the pectic polysaccharides. Carbohydrate Polymers, 45, 315-323.

Watrelot, A. A, Le Bourvellec, C., Imberty A., \& Renard, C. M. G. C. (2013). Interactions between pectic compounds and procyanidins are influenced by methylation degree and chain length. Biomacromolecules, 14, 709-718.

Watrelot, A. A., Le Bourvellec, C., Imberty, A., \& Renard, C. M. G. C. (2014). Neutral sugar side chains of pectins limit interactions with procyanidins. Carbohydrate Polymers, 99, 527-536.

Watrelot, A. A., Tran, D. T., Buffeteau, T., Deffieux, D., Le Bourvellec, C., Quideau, S., et al. (2016). Immobilization of flavan-3-ols onto sensor chips to study their interactions with proteins and pectins by SPR. Applied Surface Science, 371, $512-518$.

Williamson, G. \& Clifford, M. N. (2010). Colonic metabolites of berry polyphenols: The missing link to biological activity? British Journal of Nutrition, 104, S48-S66.

Yacco, R. S., Watrelot, A. A., \& Kennedy, J. A. (2016). Red wine tannin structureactivity relationships during fermentation and maceration. Journal of Agricultural and Food Chemistry, 64(4), 860-869.

Ye, M., Yue, T., \& Yuan, Y. (2014). Evolution of polyphenols and organic acids during the fermentation of apple cider. Journal of the Science of Food and Agriculture, 94(14), 2951-2957. 